\title{
Management and Recommendations of Nautical Simulators and Laboratory: Multiple-Site Case Study
}

\author{
Arleiny $^{1 *}$, Yoyok Soesatyo ${ }^{2}$, Erny Roesminingsih ${ }^{3}$ \\ 1,2,3Universitas Negeri Surabaya, Surabaya, Indonesia
}

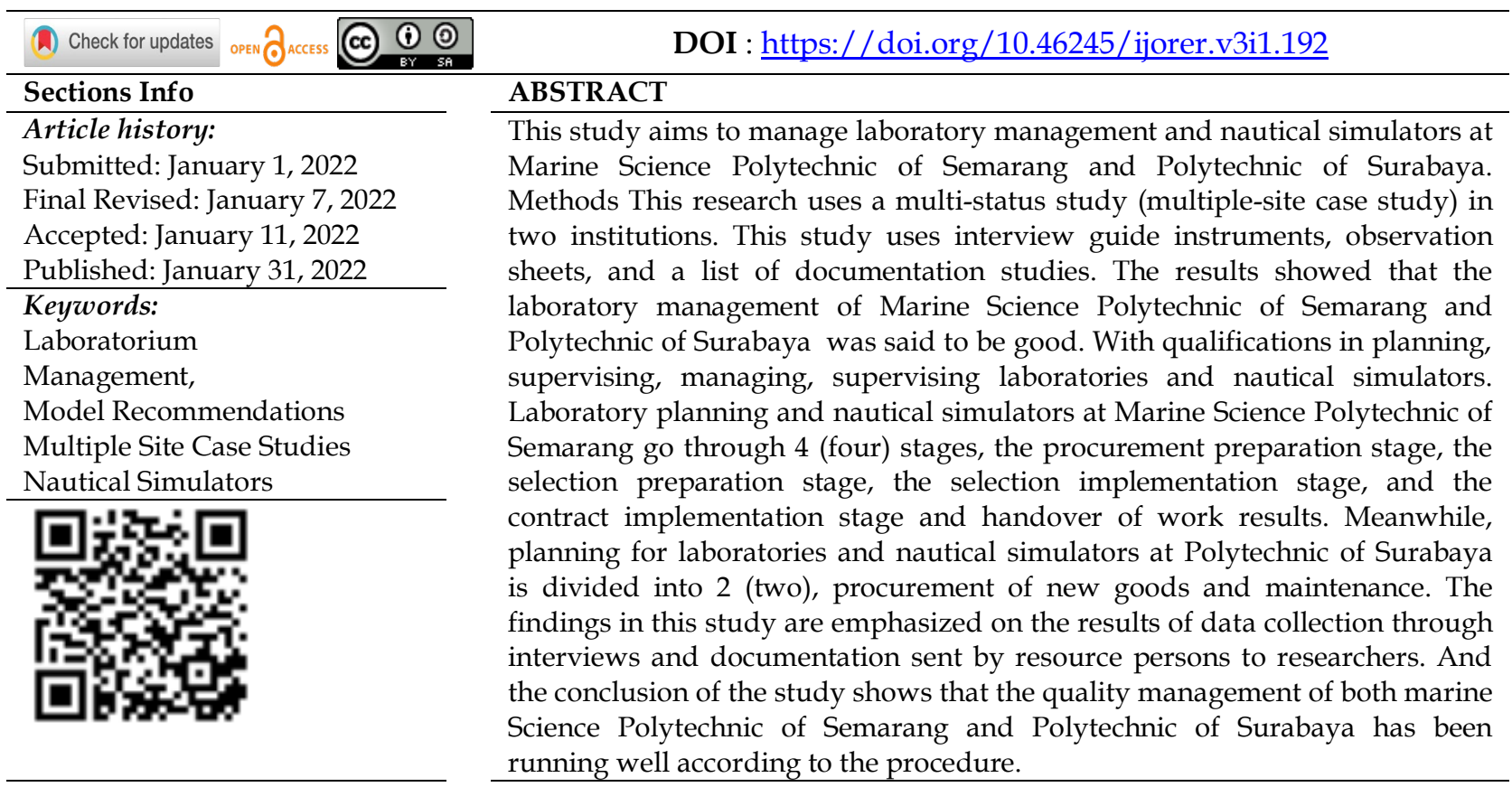

\section{INTRODUCTION}

Indonesia is an archipelagic country that has 17,504 islands. These islands are surrounded by a very wide sea of almost 5.8 million $\mathrm{km} 2$, leaving $2 / 3$ of the area as an ocean. With this area covered by seawater, Indonesia takes advantage of the potential to become a maritime axis country in Asia and internationally (Rustam, 2020). As a maritime axis, the development of the shipping industry and fishing industry is also increasing (Saragi et al., 2018). The increase in the shipping industry is indicated by data that there is an increase in the number of ships with a carrying capacity of 3,000 TUEs totaling 13 in 2019. This condition indicates that there is an increase in the volume of ship transport (Bappenas, 2019).

The increasing volume of ship transport is a sign that Indonesia's maritime sector is moving forward (Santoso et al., 2019). However, this increase in the volume of ship transportation is not supported by the availability of human resources (HR). There is a release from the Ministry of Transportation (2020) at this time. Indonesia still lacks skilled human resources for sea transportation shipping, shipping, machinery, ports, fishing technology, marine aquaculture technology, and marine product processing technology (Setiawan et al., 2021). Maritime human resources available as many as 340 thousand seafarers, with 262 people working in the country and 78 thousand people working abroad (Sitoris, 2016). This amount still cannot cover the need for human resources in the marine sector, there is still a shortage of 18 thousand seafarers at the officer level and 25 thousand at the branch level. 
The need for maritime human resources is very lacking when viewed from the quantity (Lesmini \& Purwanto, 2017). Therefore, it is necessary to increase the quantity and quality of human resources. Quality needs to be done as an effort to educate and train human resources as an effort to improve at this time (Sudarsana, 2016). Education in Maritime Education institutions and similar to Shipping Polytechnics is an important reason to increase the quantity and quality of maritime HR needs in Indonesia (Herlambang \& Setiawan, 2017). This education itself is related to the supply of human resources in the waters, ports and their safety on both commercial and non-commercial shipping. The need for shipping human resources can be obtained through the role of this maritime educational institution (Harsono, 2020).

However, the existence of the above maritime educational institutions such as the Maritime Science Polytechnic (PIP) Semarang and the Surabaya Poltekpel still does not meet the supply and demand. There is very little demand for maritime personnel. Marine Science Polytechnic of Semarang and Poltekpel can only meet percent of the total demand for maritime personnel. Moreover, currently maritime personnel are required to have superior quality (Hidayat, 2021; Daris, 2019), have high IT skills and be able to operate tools proficiently (Pratama \& Iryanti, 2020). Demands in the real world of work like this are a challenge in itself at Marine Science Polytechnic of Semarang educational institutions and Surabaya Poltekpel.

The characteristics of the two institutions that have similarities and differences make the analysis interesting, but this study does not examine the overall management of the laboratories and simulators owned by the two institutions. The research was limited to laboratories and navigation simulators because, in these laboratories and simulators, the highest number of damage to facilities and infrastructure was found compared to other laboratories and simulators. damage to facilities and infrastructure will interfere with learning and training activities (Amalia \& Maryati, 2021). Both educational institutions are vocational education institutions that are quite prominent and have produced many graduates, especially for competence in the shipping field.

This analysis considers not only the similarities between the two institutions but also the differences between them. This condition is the basis for conducting multi-site studies at the two educational institutions with a focus on laboratory management and nautical simulators. The laboratory and simulator were chosen as research subjects, because for both educational institutions the laboratory and simulator are learning facilities and media to educate students in exploring, shaping, and building cognitive, affective, psychomotor, and intuitive potentials. So based on the explanation that has been explained, the researcher intends to research laboratory management and nautical simulators at Marine Science Polytechnic of Semarang and Polytechnic of Surabaya. The objective of this research was to describe and analyze the planning, organization, implementation and supervision of laboratories and nautical simulators at the Semarang Maritime Sciences Polytechnic and Surabaya Polytechnic.

\section{RESEARCH METHOD \\ General Background}

This study uses a qualitative design. The reason for using a qualitative design is because this study aims to describe and analyze the phenomenon of the two-place site. In addition, because the research aims to describe the current state of the object of research by describing the facts that occurred. In general, this research is also field research with the type of case study, namely a multi-case study. The type of multi- 
status study (multiple-site case study) in this research is to analyze in-depth data regarding the management of laboratories and simulators in different places, namely Marine Science Polytechnic of Semarang and Polytechnic of Surabaya .

\section{Participants}

This research was conducted at Marine Science Polytechnic of Semarang and Polytechnic of Surabaya regarding the use of laboratories and navigation simulators. The sampling technique was carried out based on the similarities and characteristics that were almost the same by the two places but had special characteristics that stood out from the two institutions.

\section{Instrumen and Data Collection}

This study uses interview guide instruments, observation sheets, and a list of documentation studies. The three instruments used were made based on the research focus assisted by theoretical studies. Then the data collection technique was carried out through in-depth interviews or in-depth interviews with several informants, observation, and documentation.

\section{Data Analysis}

Multi-site case study research on laboratory and simulator management, the data analysis used is an analysis that adopts the analysis process of Miles. The data analysis process includes stages in the form of 1) data condensation, 2) data presentation, 3) data collection, 4) conclusion drawing. The design of the research qualitative data analysis model is presented in Figure 1.

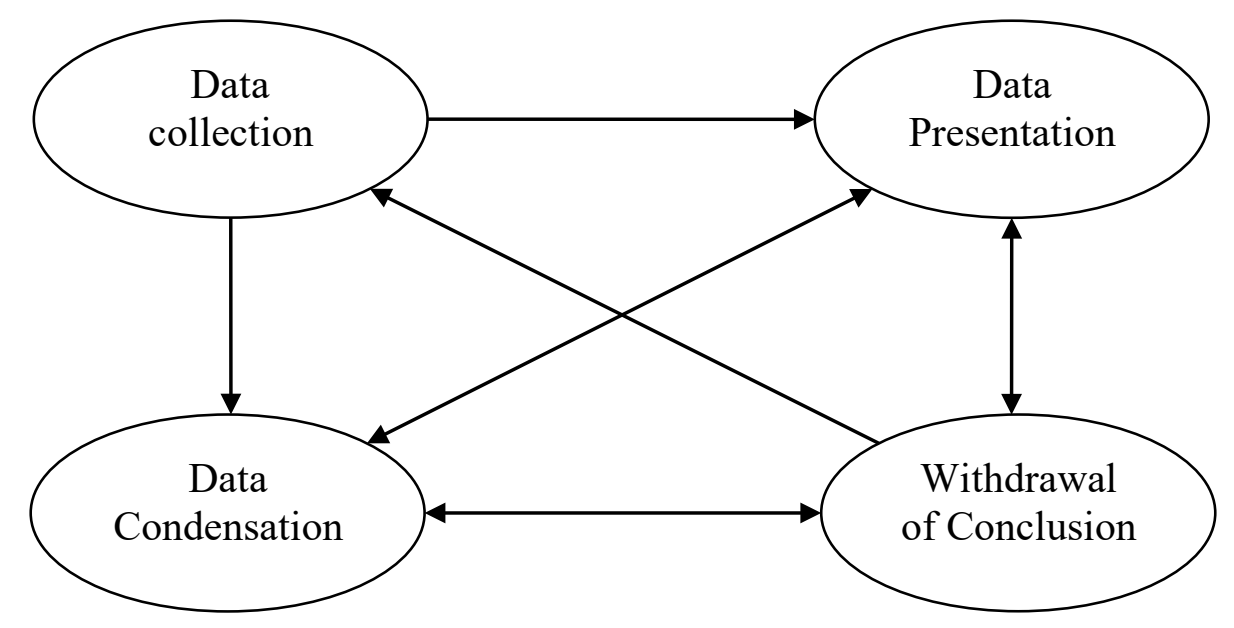

Figure 1. Design of research qualitative data analysis model.

\section{Procedure and Research Design}

This research was designed with a multi-site case study. The research design of a multisite study was carried out with the following procedures; 1 ) develop theory to be able to lead to case selection; 2) the process of collecting and selecting data on each site; 3) perform data analysis for each site, 4) cross-site analysis; and 5) conclude from the research results. The research design procedure is described in the form of a flowchart in Figure 2. 


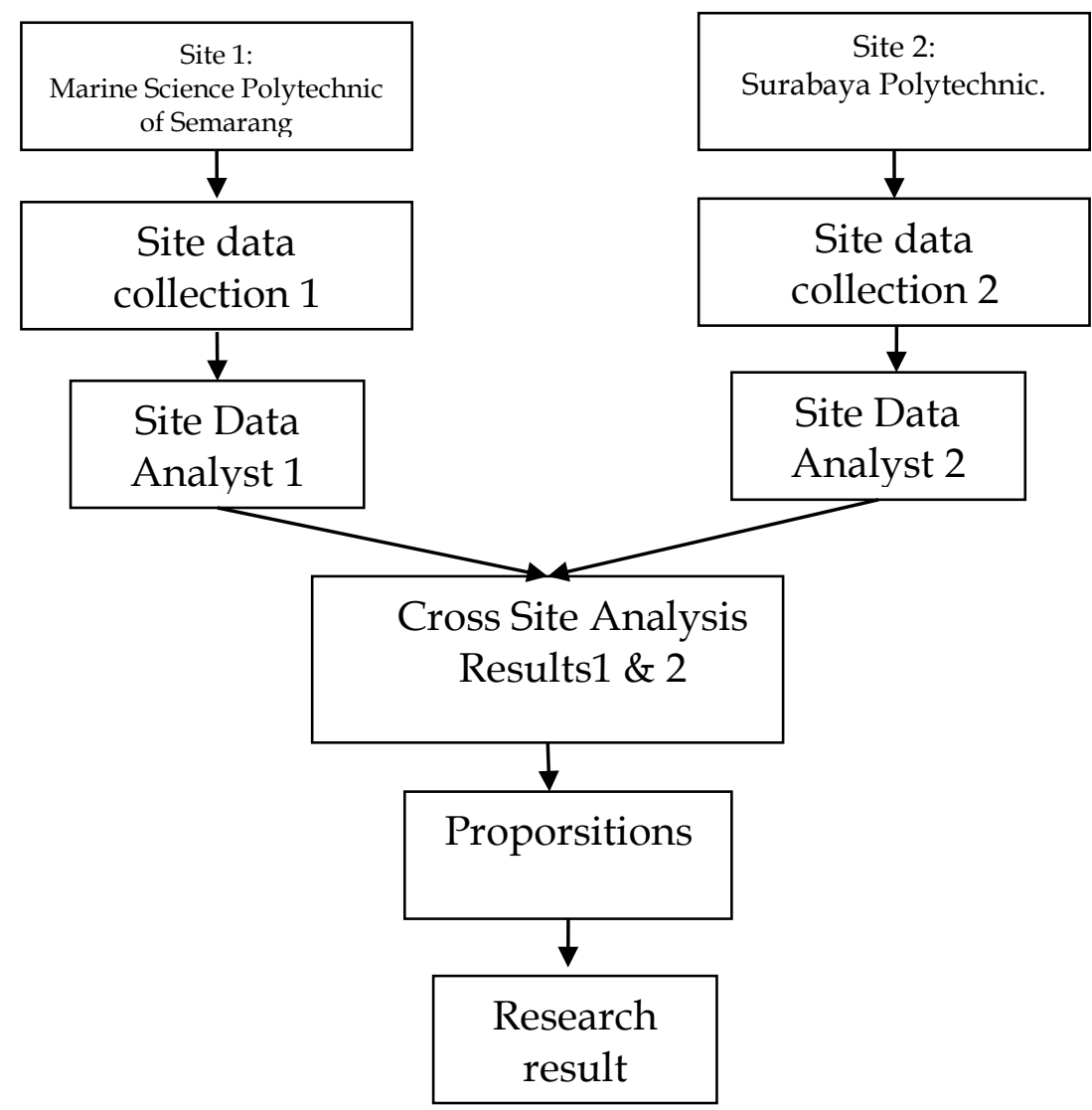

Figure 2. Flowchart research from marine science polytechnic of semarang and surabaya polytechnic.

\section{RESULTS AND DISCUSSION}

Laboratory Planning and Nautical Simulator at Marine Science Polytechnic of Semarang and Polytechnic of Surabaya

Laboratory planning and nautical simulators have their plans and the technician team has their respective duties and roles. The staff at Polytechnic of Surabaya have their respective duties, which are divided into several sections. Each staff knows laboratory and nautical facilities and infrastructure. The need for planning goods owned by Polytechnic of Surabaya is obtained as follows.

Tabel 1. Material for planning.

\begin{tabular}{clcl}
\hline No & Materials needed & Needs per group & Unit \\
\hline 1 & Life Buoy & 15 & item \\
2 & Life Jacket & 100 & item \\
3 & Red Hand Flare & 100 & item \\
4 & Smoke Signal & 100 & item \\
5 & Safety shoes & 50 & pair \\
6 & Masker & 10 & item \\
\hline
\end{tabular}

Laboratory planning and nautical simulators are divided into 2 (two) namely procurement of new goods and maintenance, every month the technician team reports if there is damage, then the procurement team decides to replace it or just do maintenance. The following is a list of maintenance and procurement at Poltekpel 2019. 


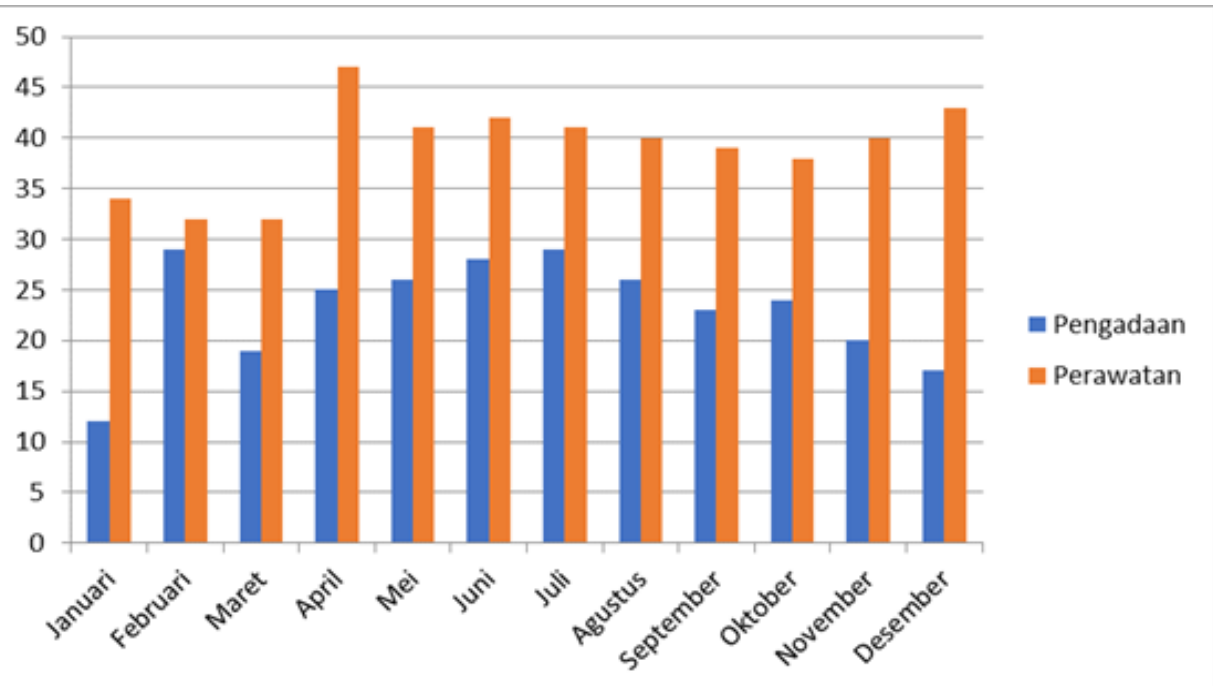

Figure 1. Number of procurement and maintenance at poltekpel in 2019.

Based on the chart table above, it can be concluded that the planning of the laboratory and sim simulator is more for the maintenance of facilities and infrastructure than the procurement of goods. The difference in numbers which is quite significant between procurement and maintenance, the number of maintenance of facilities and infrastructure is quite high, which can minimize the budget that comes out. Wiratma (2015) states that good management does not only increase the procurement of goods but also requires intense maintenance. Based on the results of an in-depth analysis based on interviews and the results of data checks, it was found that planning findings by the Marine Science Polytechnic of Semarang poltekpel were 1) Planning (planning) carried out by Marine Science Polytechnic of Semarang was the process of deciding what activities, how to carry them out, when, and by whom. 2) Planning is done to avoid mistakes in taking actions that cause losses for Marine Science Polytechnic of Semarang. 3) Planning is determined carefully for everything that will be carried out, what resources are provided to support its implementation (humans, laboratory materials and equipment, budget), a schedule of activities that includes the target time needed to carry out all processes. 4) Planning here is a systematic, analytical, logical thought process about the activities that must be carried out, the steps, methods, human resources, energy, and funds needed to achieve the goals that have been determined effectively and efficiently. 5) Planning is intended to plan the concept of a laboratory and the nautical simulator itself. This means that before the laboratory is built, one must first know for what purposes and for whom the laboratory is used.

In Marine Science Polytechnic of Semarang, planning is carried out in several stages, namely the procurement preparation stage, the selection preparation stage, the selection implementation stage, and the contract implementation stage and handover of the work, while at the Surabaya Poltekpel using two ways, namely with new maintenance and maintenance, for the maintenance of new goods. . For maintenance of old goods with two stages, namely maintenance by technicians or by vendors from the laboratory and simulator.The results of the planning findings at Marine Science Polytechnic of Semarang and Surabaya obtained the arrangement of the diagrams in Figure 2 and Figure 3. 


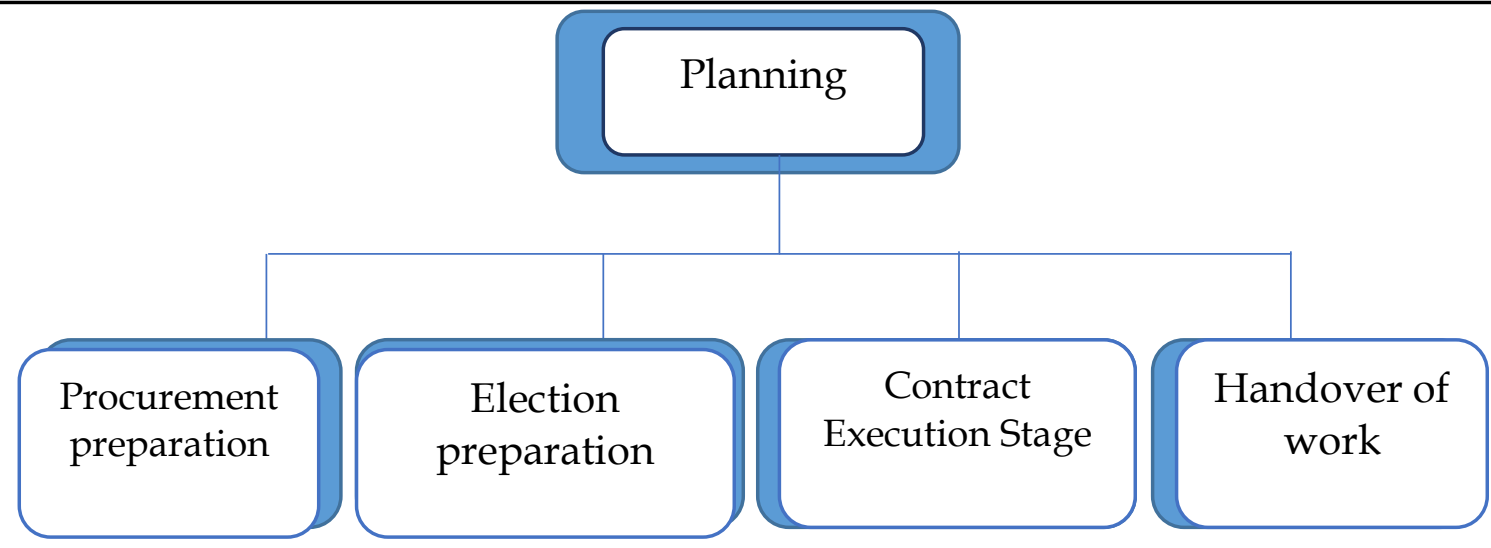

Figure 2. Planning at marine science polytechnic of semarang.

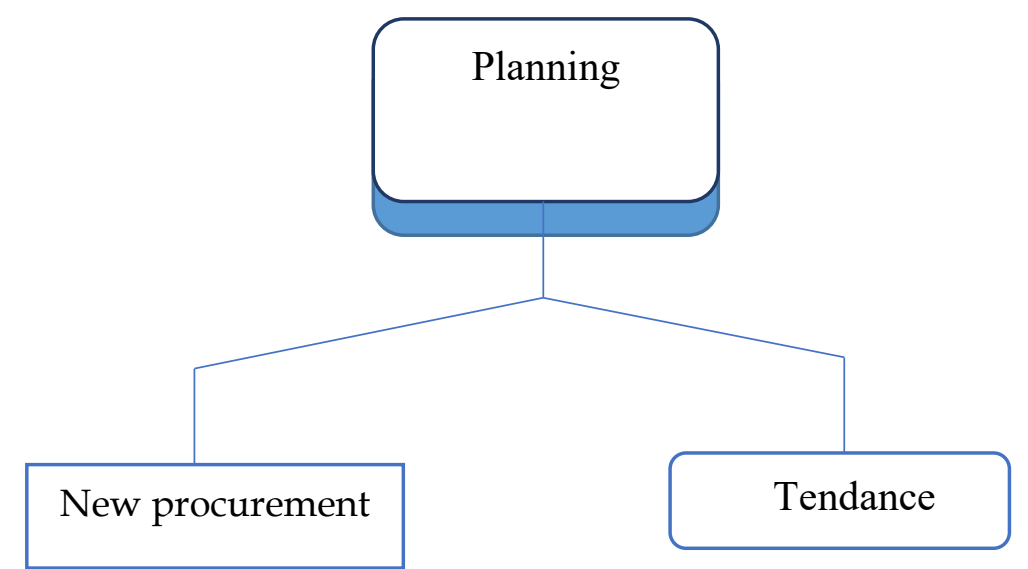

Figure 3. Planning at the surabaya shipping polytechnic.

Organization of Laboratory and Nautical Simulator at Marine Science Polytechnic of Semarang and Polytechnic of Surabaya .The organization of laboratories and nautical simulators at Polytechnic of Surabaya is by dividing the tasks of each technician in each laboratory or nautical simulator. Each technician holds several laboratories and simulators, organizes laboratories and nautical simulators by taking care of the facilities and infrastructure every day before they are used by cadets or training participants. Researchers took data through interviews by several informants or sources. One of the interviews was conducted by informant TL $2 \mathrm{~d}$. that is.

"If what I do I leave it neglected, the treatment is only physically cleaning, Ms. Clean the room and keep the equipment, those are special tools too. Sometimes we have to go to a vendor who does it like that. In certain cases, we can't do the maintenance ourselves, right, we have to call someone. Yes, for now that is the condition, because most of the activities are on campus 2 here." (TL2D. W.10. 89-98)"

Based on the interview excerpt, one laboratory room or nautical simulator is used in turn by the cadets and all cadets must learn to practice in the laboratory or nautical simulator room. The limited space makes sometimes every class over time in the use of the laboratory or nautical simulator. If the use of laboratories and nautical simulators is over time, one class must give in, or use the option of dividing into two groups in each practice. This will reduce the level of damage to the laboratory (Geetha, 2021; Suseno et al., 2019; Nurabadi et al., 2018). 
So based on the activities of organizing the two places between Marine Science Polytechnic of Semarang and Poltkpel Surabaya the following results were obtained, recording equipment, making item codes, reporting goods, lighting, laboratories must be designed in such a way as to avoid direct sunlight penetration, making room ventilation so that air contamination does not occur. as a result of chemical experimentation. Sufficient energy sources, adequate water supplies, and the last is the existence of safety facilities.

Implementation of Nautical Laboratory and Simulator at Marine Science Polytechnic of Semarang and Polytechnic of Surabaya

The implementation of the laboratory and nautical simulator at Polytechnic of Surabaya is used in turn by each cadet due to space limitations. All cadets must practice even though the use of laboratories and nautical simulators is used alternately. There is one of the interview results obtained during the data collection process, namely:

"For one class, usually, 23 people have already been appointed. Seven people entered. Usually two hours. One lesson. Depending on the teacher, maybe 30 minutes. As much as possible all should be. Must all. I don't know if it will be overtime or how everything has to be. Maybe the teacher is wrong. It's okay, if it's not like that, for example, in this lab, there are four trends and then they change it, sharing two pieces of training and two pieces of training." (TL2A. W.07. 81-110)"

Meanwhile, the implementation of the Semarang PIP laboratory and simulator has been regulated by standard operating procedures (SOP) for the use of laboratories and simulators. In anticipation of supporting implementation during the process of using laboratory work units and simulators, carrying out management implementation involves three things, namely maintenance, storage, and deletion. So far, the obstacles in carrying out laboratory maintenance and maintenance occur when repairs must involve third parties/vendors. Almost all of the vendors for simulators at Marine Science Polytechnic of Semarang come from abroad, which costs a lot of money to bring them in. So that the overall implementation of the SOP laboratory and simulator has been carried out according to SOP standards. SOPs are required during the implementation process. In working in the laboratory, it is also necessary to anticipate existing accidents. And accidents often occur due to negligence and attitude factors (Indrayani \& Sulianti, 2014). So it is very necessary to first educate practitioners in the implementation of laboratories and simulators (Darwin \& Budiyanto, 2021).

\section{Laboratory Supervision and Nautical Simulator at Marine Science Polytechnic of Semarang and Polytechnic of Surabaya.}

Supervision of facilities and infrastructure is carried out in almost every practical activity that takes place in all laboratories and simulators belonging to Marine Science Polytechnic of Semarang. One form of supervision carried out is to record and recap the utility reports on the use of laboratories and simulators. The report obtained shows the number of uses that are not evenly distributed in each laboratory and simulator at Marine Science Polytechnic of Semarang. This happens due to several factors, one of which is several simulator functions that are almost the same. The fact that teachers in observing practicum activities are often involved with corrections for cadet students' practicum preparations so that the observations made have not been maximized. As a 
limitation of supervision carried out by lecturers, sometimes technicians are involved in supervising every practicum activity (Imansari, 2017).

Based on the research findings, it shows that the laboratory and simulator supervision of Marine Science Polytechnic of Semarang 1) Supervision of practical equipment is by good SOP principles, starting from making a list of needs based on a priority scale by adjusting the available funds, 2) Supervision of the use of simulators in cadet student learning detailed up to the daily schedule to the monthly schedule, 3) Supervision of the procurement of practical materials does not meet the elements of administrative financial accountability. 3) Laboratory supervision has been carried out properly, especially by the head of the laboratory and the laboratory coordinator. While the administration is still very lacking. This can be seen from several laboratory administration books that have not been filled in for a long time. 4) Supervision of new laboratory maintenance and repairs is carried out on the physical condition of the building and furniture, while practical tools are still neglected. 5) Supervision includes the laboratory substantially has been running well but managerially the administration is not neat or orderly such as the register of laboratory users, there are still some steps that are often missed.

Then the supervision of laboratories and nautical simulators at Polytechnic of Surabaya includes checking the inventory list of laboratory needs and nautical simulators, utilities using laboratories and simulators, carrying out maintenance and repairs on laboratories. Where the results of in-depth interviews conducted by researchers related to laboratory supervision and the Surabaya Polytechnic nautical simulator obtained important points. The research findings show that laboratory supervision is carried out as follows: 1) Supervision of practical tools is by good SOP principles, starting from making a list of needs based on a priority scale by adjusting the available funds. 2) Supervision of the use of simulators in detailed cadet student learning up to the daily schedule to the monthly schedule. 3) Supervision of the procurement of practical tools does not meet the elements of administrative financial accountability. 4) Laboratory supervision has been carried out properly, especially by the head of the laboratory and the laboratory coordinator. While the administration is still very lacking. This can be seen from several laboratory administration books that have not been filled in for a long time. 5) Supervision of new laboratory maintenance and repairs is carried out on the physical condition of the building and furniture, while practical tools are still neglected. 6) Supervision includes the laboratory substantially has been running well but managerially the administration is not neat or orderly such as the register of laboratory users, there are still some steps that are often missed. The results above show that supervision is very important in improving organizational and laboratory quality management (Nurabadi et al., 2018). It really needs more detailed supervision so that the laboratory is well maintained, and all facilities are durable and well-maintained. Turrahmah et al. (2020) states that a good effort in maintaining a laboratory begins with anyone who is involved and arranges it in a professional and structured organization so that facilities and infrastructure can be controlled safely.

\section{Recommended Model}

Monitoring of laboratories and nautical simulators at Polytechnic of Surabaya includes checking the inventory list of laboratory needs and nautical simulators, utilities using laboratories and simulators, performing maintenance and repairs on laboratories (Turrahmah et al., 2020). From the results of the multi-case study analysis from the two 
research sites, namely Marine Science Polytechnic of Semarang and Polytechnic of Surabaya, the results of the model recommendations developed by the researchers were obtained to obtain better management. The recommendation model is shown in Figure 4 and 5.

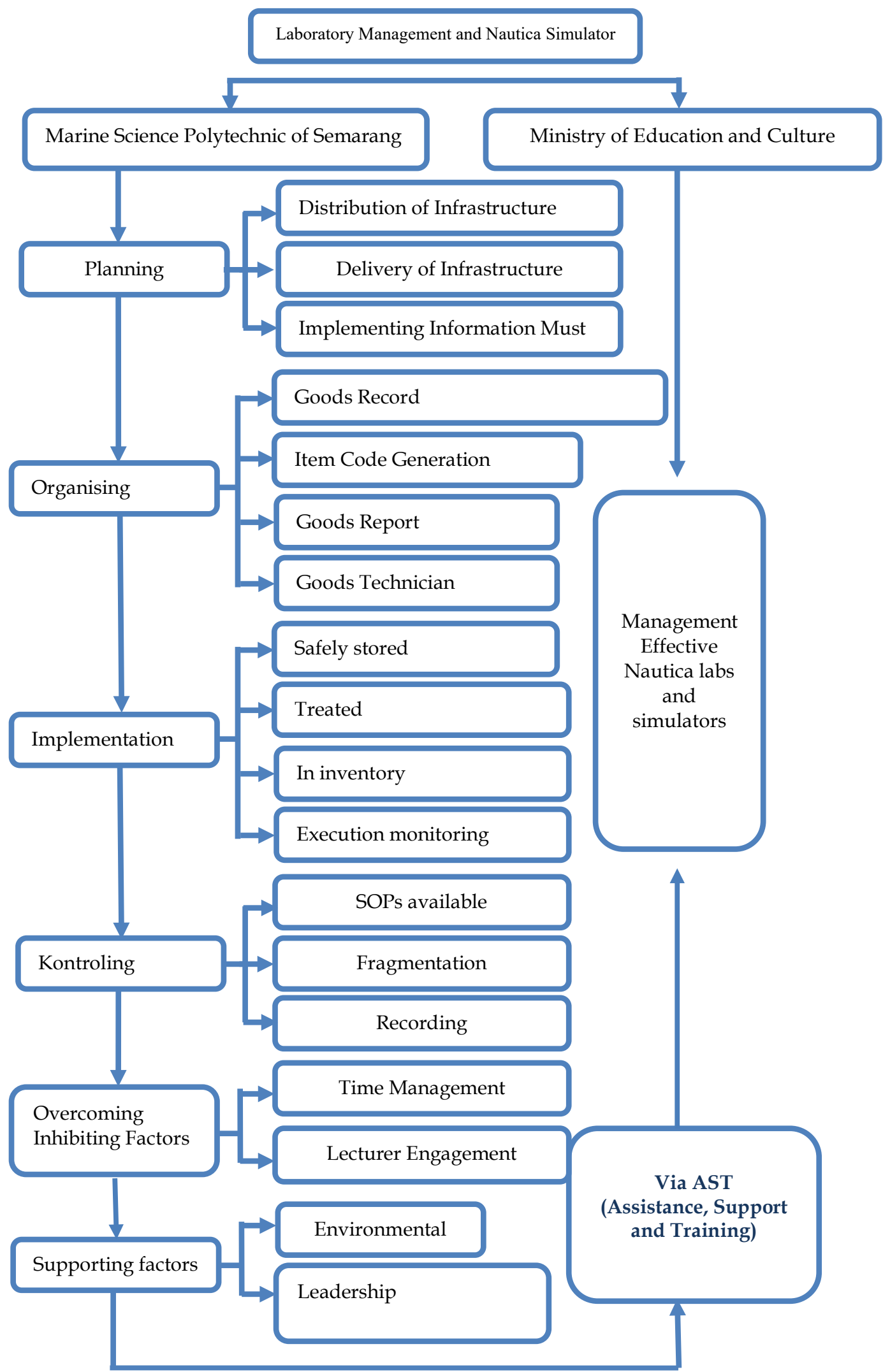

Figure 4. Management recommendations at marine science polytechnic of Semarang. 
Laboratory and Nautica simulator management starts from the planning agenda, organizing to the implementation stage. The concept which states that realizing a laboratory objective is effective is by G Terry's theory. This theory states that successful implementation involves four basic components that must be considered, plus routine and steady laboratory control and Nautica simulators. The implementation of lectures that have been initiated and implemented by Marine Science Polytechnic of Semarang and Polytechnic of Surabaya has been maximized. This indicates that the initial purpose of manufacture and equipment has been achieved optimally. Turrahmah et al. (2020) states that if the goals are well structured and the performance is active, it will tend to get results above the standard.

This condition can be seen in Marine Science Polytechnic of Semarang with the maximum use of planning. For example, lectures are still combined in class and the practice room with other campus activities. Resources as the second element are seen to be widely owned, namely, lecturers who have pedagogic competence of skills, almost entirely sufficient and supportive. Pedagogy skills can provide support and motivation (Triastika \& Rahman, 2017; Malichatin, 2019). Based on the research findings and discussion above, this research produces a laboratory model and a Nautica simulator called the perfect laboratory and simulator Nautica model.

Then, based on the analysis of the needs and conditions of the laboratory and the nautica simulator model of the Polytechnic of Surabaya, a recommendation model from the researchers was obtained which was designed with the exposure of Figure 2. The results of the recommendation model chart in Figure 8 show that management begins with planning, organizing, implementing, controlling, overcoming factors, and analyzing what are the supporting factors of the Surabaya Poltekpel. The researcher recommends several designs to improve the management of Polytechnic of Surabaya so that the control process is much better. The design presented in the form of a recommendation model design is almost similar to the design model from Marine Science Polytechnic of Semarang.

Planning for laboratories and simulators at Marine Science Polytechnic of Semarang goes through 4 stages, namely procurement, preparation for selection, implementation of elections, and implementation of contracts and handover of work results. Meanwhile, planning for laboratories and nautical simulators at Polytechnic of Surabaya is divided into 2 (two), procurement of new goods and maintenance. The technicians also carry out the organization of laboratories and nautical simulators by procuring goods every 3 months. The implementation of laboratories and nautical simulators at Polytechnic of Surabaya in terms of equipment is often not by what was ordered by the technician team, the quality provided by the procurement field is far from the order so that the ordered facilities can be used only a few times if it is not too damaged it can still be used but if heavily damaged, the technician will make a report and then make an official note for the procurement of new goods (Turrahmah et al., 2020; Pangestu \& Sukardi, 2019). Supervision of laboratories and nautical simulators is carried out in 3 (three) ways, namely by checking the inventory list for laboratory needs and nautical simulators and carrying out maintenance and repairs on the laboratory. The weakness of this research is that at the planning stage it only made observations at both sites after data collection through interviews was completed, which was around February 2020, but only made several visits to make observations. Then during the study experienced problems related to the procurement of life jackets, so further research was needed by recommending deeper studies related to life jackets. Is the life jacket worthy of being 
included in the capital goods category at Polytechnic of Surabaya because at Marine Science Polytechnic of Semarang the life jacket is included in the consumables category, although previously it was in the capital goods category.

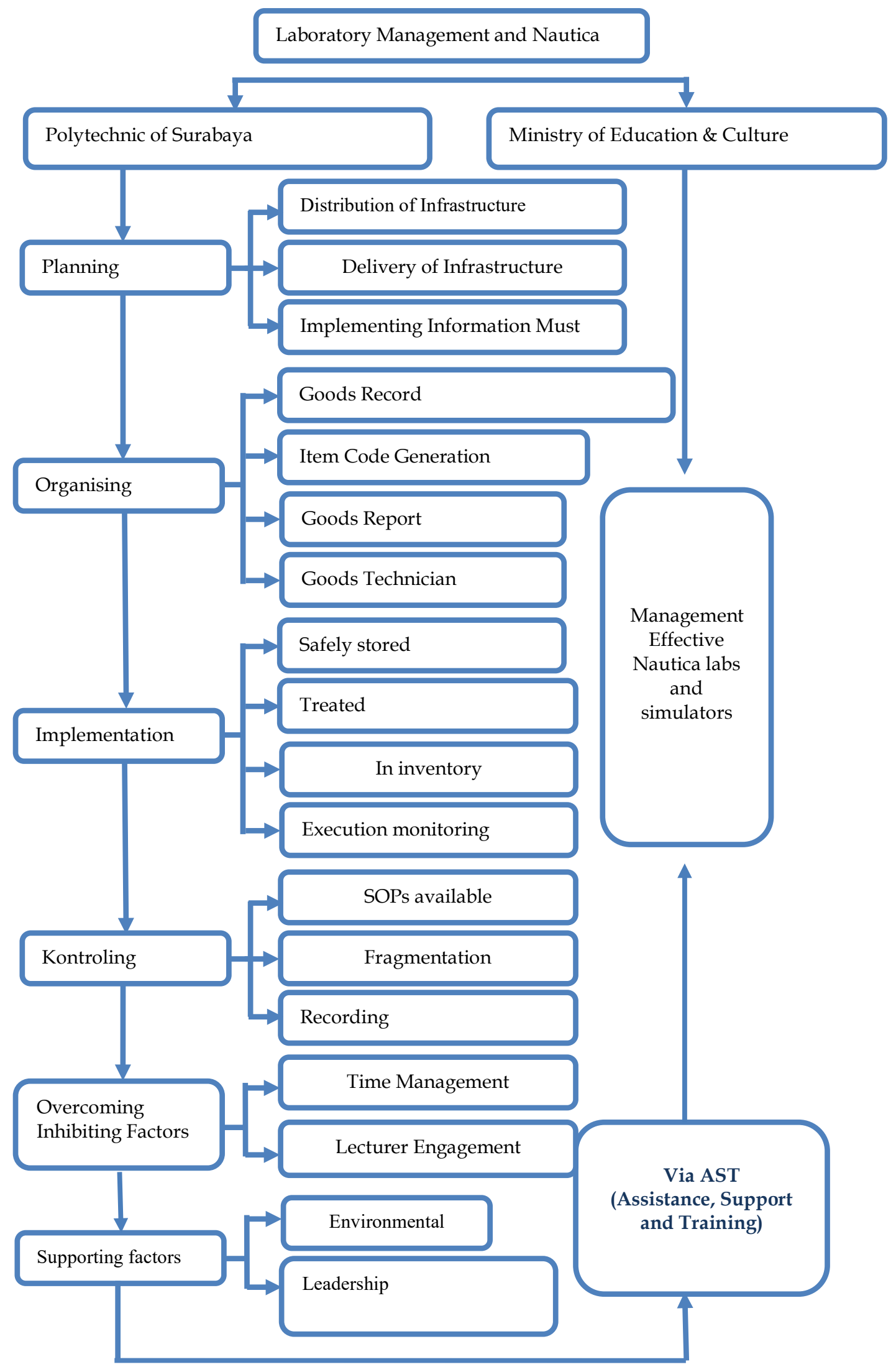

Figure 5. Management recommendations at marine science polytechnic of Semarang. 


\section{CONCLUSION}

Planning for laboratories and simulators at Marine Science Polytechnic of Semarang goes through 4 stages, namely procurement, preparation for selection, implementation of elections, and implementation of contracts and handover of work results. Meanwhile, planning for laboratories and nautical simulators at Polytechnic of Surabaya is divided into 2 (two), procurement of new goods and maintenance. The technicians also carry out the organization of laboratories and nautical simulators by procuring goods every 3 months. The implementation of laboratories and nautical simulators at Polytechnic of Surabaya in terms of equipment is often not by what was ordered by the technician team, the quality provided by the procurement field is far from the order so that the ordered facilities can be used only a few times, if it is not too damaged it can still be used but if heavily damaged, the technician will make a report and then make an official note for the procurement of new goods. Supervision of laboratories and nautical simulators is carried out in 3 (three) ways, namely by checking the inventory list for laboratory needs and nautical simulators, and carrying out maintenance and repairs on the laboratory. The weakness of this research is that at the planning stage it only made observations at both sites after data collection through interviews was completed, which was around February 2020, but only made several visits to make observations. Then during the study experienced problems related to the procurement of life jackets, so further research was needed by recommending deeper studies related to life jackets. Is the life jacket worthy of being included in the capital goods category at Polytechnic of Surabaya because at Marine Science Polytechnic of Semarang the life jacket is included in the consumables category, although previously it was in the capital goods category.

\section{REFERENCES}

Amalia, L., \& Maryati, M. (2021). Pengelolaan sarana dan prasarana pendidikan di madrasah aliyah negeri 2 Karawang. PeTeKa: Jurnal Penelitian Tindakan Kelas dan Pengembangan Pembelajaran, 4(2), 205-213. http://dx.doi.org/10.31604/ptk.v4i2.205-213

Daris, L. (2019). Kurikulum pendidikan berbasis maritim di era revolusi industri 4.0. Penguatan Pendidikan Karakter Di Era Revolusi Industri, 4(10), 10-15.

Darwin \& Budiyanta, N. E. (2021). Rancang bangun sistem peminjaman dan manajemen aset laboratorium berbasis implementasi RFID dan aplikasi web. Jurnal Edukasi Elektro, 5(2), 80-90. https://doi.org/10.21831/jee.v5i2.43472

Geetha, K. (2021). E-Laboratory in education system. Turkish Journal of Computer and Mathematics Education, 12(10), 1420-1424. https://doi.org/10.17762/turcomat.v12i10.4448

Harsono, S. (2017). Analisis faktor-faktor yang mempengaruhi kinerja dosen dan implikasinya pada kesejahteraan dosen perguruan tinggi maritim. Kontigensi: Jurnal Ilmiah Manajemen, 5(1), 14-24. https://doi.org/10.5281/zenodo.3375336

Herlambang, S. M., \& Setiawan, R. N. A. (2017). Studi kelayakan pembukaan program studi ketatalaksanaan angkutan laut dan kepelabuhanan (KALK) politeknik pelayaran Surabaya. Jurnal 7 Samudra, 2(1), 1-10.

Hidayat, A. N. (2021). Pengembangan model video pembelajaran kewirausahaan dan pendidikan kecakapan hidup di PKBM maritim kecamatan labuan kabupaten Pandeglang. E-Jurnal Pendidikan Mutiara, 6(2), 12-22.

Imansari, N. (2017). Manajemen laboratorium pendidikan teknik elektro (studi kasus di fkipuniversitas PGRI Madiun). JUPITER: Jurnal Pendidikan Teknik Elektro, 2(1), 1-7. http://doi.org/10.25273/jupiter.v2i1.1735

Indrayani, I., \& Sulianti, I. (2014). Kajian Penerapan kesehatan dan keselamatan kerja (K3) dalam proses belajar mengajar di bengkel dan laboratorium politeknik negeri Sriwijaya. PILAR, 10(1), 27-36. 
Khazri, Y., Al Sabri, A., Sabir, B., Toumi, H., Moussetad, M., \& Fahli, A. (2017). Development and management of a remote laboratory in physics for engineering education (E-LAB FSBM). BDCA'17: Proceedings of the 2nd international Conference on Big Data, Cloud and Applications, 3(103), 1-6. https://doi.org/10.1145/3090354.3090460

Lesmini, L., \& Purwanto, B. (2017). Ekonomi maritim \& sumber daya manusia Indonesia. Jurnal Manajemen Bisnis Transportasi Dan Logistik, 2(3), 372-389.

Malichatin, H. (2019). Analisis kemampuan technological, pedagogical, and content knowledge mahasiswa calon guru biologi melalui kegiatan presentasi di kelas. Journal of Biology Education, 2(2), 162-171.

Nurabadi, A., Sucipto, J., Juharyanto, J., \& Gunawan, I. (2018). The implementation of education management standards in the school laboratory state university of Malang for improving educational quality. Atlantis Press.

Pangestu, F., \& Sukardi, S. (2019). Evaluation of the implementation of workshop and laboratory management on vocational high school. Jurnal Pendidikan Vokasi, 9(2), 172-184. https://doi.org/10.21831/jpv.v9i2.25991

Pratama, H. A., \& Iryanti, H. D. (2020). Transformasi SDM dalam menghadapi tantangan revolusi 4.0 di sektor kepelabuhan. Majalah Ilmiah Bahari Jogja, 18(1), 71-80. https://doi.org/10.33489/mibj.v18i1.229

Purwantini, V. T., \& Suwarni, E. S. (2015). Analisa perbedaan kepuasan mahasiswa S1 akuntansi dan s1 manajemen Sekolah Tinggi Ilmu Ekonomi Adi Unggul Bhirawa Surakarta. BHIRAWA: Jurnal of Marketing and Commerce, 2(2), 23-33.

Rustam, I. (2020). Strategi maritime silk road China dan dampaknya pada keamanan maritim Indonesia. Indonesian Journal Of Peace And Security Studies (IJPSS), 2(2), 31-50.

Santoso, A., \& Zaman, M. B. (2019). Permesinan bantu pada kapal moder, permesinan geladak. Airlangga University Press.

Saragi, F. K., Mamahit, D. A., \& Prasetyo, T. Y. B. (2018). Implementasi pembangunan tol laut untuk mewujudkan Indonesia sebagai poros maritim dunia. Jurnal Keamanan Maritim, 4(1), 69-92.

Setiawan, H. D., \& Sudja, M. D. (2021). kompetensi sumber daya manusia kelautan di $\begin{array}{llll}\text { Indonesia. Jurnal dimu 290-305. } & \text { Budaya, 42(2), }\end{array}$ http:/ / dx.doi.org/10.47313/jib.v42i2.1442

Sitoris, H. (2016). Meningkatkan SDM kemaritiman. Analisadaily.

Sudarsana, I. K. (2016). Peningkatan mutu pendidikan luar sekolah dalam upayapembangunan sumber daya manusia. Jurnal Penjaminan Mutu, 1(1), 1-14. http://dx.doi.org/10.25078/jpm.v1i1.34

Suseno, N., Harjati, P., \& Dedy, H. A. (2019). School laboratory management information system. Journal of Physics: Conference Series, 1361(012068), 1-9.

Triastika, A., \& Rahman, I. (2017). Designing liner shipping network in Indonesia with demand uncertainty. GEOMATE Journal, 13(36), 87-93.

Turrahmah, N., Pujani, N. M., \& Selamet, K. (2020). Pengelolaan laboratorium ilmu pengetahuan alam (IPA) smp negeri 2 Singaraja. Jurnal Pendidikan dan Pembelajaran Sains Indonesia (JPPSI), 3(2), 118-129. http:/ / dx.doi.org/10.23887/jppsi.v3i2.29592

Wiratma, I. G. L. (2015). Pengelolaan laboratorium kimia pada sma negeri di kota Singaraja: Acuan pengembangan model panduan pengelolaan laboratorium kimia berbasis kearifan lokal tri sakti. JPI: Jurnal Pendidikan Indonesia, 3(2), 425-436. http://dx.doi.org/10.23887/jpi-undiksha.v3i2.4459 


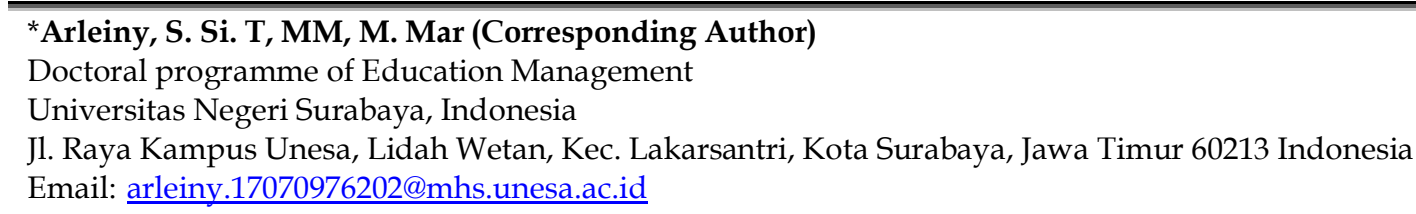

\section{Prof. Dr. H. Yoyok Soesatyo, S.H., M.M.}

Doctoral programme of Education Management

Universitas Negeri Surabaya, Indonesia

Jl. Raya Kampus Unesa, Lidah Wetan, Kec. Lakarsantri, Kota Surabaya, Jawa Timur 60213 Indonesia Email: Yoyoksoesatyo3@gmail.com

\section{Dr. Erny Roesminingsih, M.Si.}

Doctoral programme of Education Management

Universitas Negeri Surabaya, Indonesia

Jl. Raya Kampus Unesa, Lidah Wetan, Kec. Lakarsantri, Kota Surabaya, Jawa Timur 60213 Indonesia Email: ernyroesminingsih@unesa.ac.id 